9. Fishman, A. P.: Dynamics of the pulmonary circulation. In: W. F. Hamilton and P. Dow, (Eds.): Handbook of physiology, Vol. II, Section 7.: Circulation. pp. 1696-1699 (American Physiological Society, Washington, D. C., 1963).

10. Green, L. H. and Smith, T. W.: The use of digitalis in patients with pulmonary disease. Ann. Intern. Med., 87: 459 (1977).

11. Hayes, S. L., Lasseter, K. C., Davolos, D. D., and Palmer, R. F.: Amrinone-a novel cardiac inotrope: effects after oral administrations in normal man. Clin. Res., 27: 542A (1979).

12. Keung, E., LeJemtel, P. H., Ribner, H. S., Wexler, J., and Sonnenblick, E. H.: Amrinone, a new oral inotropic agent in the treatment of heart failure. Clin. Res., 7: 502A (1979).

13. Klein, N. A., Siskind, S. J., Frishman, W. H., Sonnenblick, E. H., and LeJemtel, P. H.: Hemodynamic comparison of intravenous amrinone and dobutamine in patients with chronic congestive heart failure. Am. J. Cardiol., 48: 170 (1981).

14. LeJemtel, P. H., Keung, E., Sonnenblick, E. H., Ribner, H. S., Matsumoto, M., Davis, R. Schwartz, W. Alousi, A. A., and Davalos, D.: Amrinone-a new nonglycosidic, non-adrenergic cardiotonic agent effective in the treatment of intractable myocardial failure in man. Circulation, 59: 1098 (1979).

15. Lock, J. E.: Pharmacologic approaches to the treatment of pulmonary hypertension. In: G. J. Peckham and M. A. Heymann, (Eds.): Cardiovascular Sequelae of Asphyxia in the Newborn, Report of The Eighty-Third Ross Conference on Pediatric Research. pp. 94-99 (Ross Laboratories, Columbus, 1982).

16. Lock, J. E., Hamilton, F., Luide, H., Coceani, F., and Olley, P. M.: Direct pulmonary vascular responses in the conscious newborn lamb. J. Appl. Physiol.: Respir., Environ., Exer. Physiol., 48: 188 (1980).

17. Mecca, T. E. and Caldwell, R. W.: The pulmonary vasoconstricting action of digoxin: site of action on the sympathetic nervous system. Fed. Proc. (Abstract) 441: 1608 (1982).

18. Weber, K. T., Andrews, V., Janicki, J. S., Wilson, J. R., and Fishman, A. P.: Amrinone and exercise performance in patients with chronic heart failure. Am. J. Cardiol., 48: 164 (1981).

19. Wynne, J., Malacoff, R. F., Bennoti, J. R., Curfman, T. D., Grossman, W., Holman, B. L., Smith, T. W., and Braunwld, E.: Oral amrinone in refractory congestive heart failure. Am. J. Cardiol., 45: 1245 (1980).

20. The authors would like to thank Teresa Niemi for technical and surgical assistance, Marietta Sattler for secretarial assistance, and Don Svendsen for photography.

21. Request for reprints should be addressed to: Dr. James E. Lock, Box 94 Mayo Memorial Building, University of Minnesota Hospitals, 420 Delaware Street S.E., Minneapolis, MN 55455.

22. This work was supported in part by Grant HL 28241 from the National Institutes of Health, and a grant from the American Heart Association, Minnesota Affiliate. Dr. Lock is an Established Investigator of the American Heart Association.

23. Received for publication August 3, 1982.

24. Accepted for publication February 4, 1983.

\title{
Oral Immunization to Milk Protein in Human Infants in the Presence of Passive Antibody
}

\author{
WOLFGANG MÜLLER, ${ }^{(28)}$ AXEL LIPPMANN, AND CHRISTIAN H. L. RIEGER \\ Department of Pediatrics, Medizinische Hochschule Hannover, Hannover, West Germany
}

\section{Summary}

The possible influence of maternal antibody on the immune response to bovine serum albumin (BSA), a normal cow's milk protein, was investigated in fullterm human neonates. Antibody production to BSA of 12 infants with passively acquired anti-BSA (Group I) was compared to the immune response of nine infants without passive anti-BSA at birth (Group II) during the first 6 months of life. All infants were raised on commercial cow's milk formulas containing BSA in concentrations from $0.4-4.0 \mathrm{mg} / \mathrm{dl}$. From 4 wk of age concentrations of circulating anti-BSA as measured by radioimmunoassay and enzyme-linked-immunosorbent-assay (ELISA) were higher in Group II, but differences were not statistically significant. There was no difference in the immune response between infants ingesting formulas with high BSA content compared to infants ingesting low concentrations of antigenic BSA. The main isotype associated with anti-BSA formation was IgG. IgA in measurable amounts appeared later and accounted for approximately $10 \%$ of circulating antibody in both groups at 6 months of age. Only small amounts of IgM- and IgE-anti-BSA were detected.

\section{Abbreviations}

ABC-33, antigen binding capacity-33

BSA, bovine serum albumin

BSA-N, bovine serum albumin-nitrogen

ELISA, enzyme-linked-immunosorbent assay

EU, ELISA units

GALT, gut-associated lymphoid tissue

OD, optical density
The placental transfer of specific antibodies to pathogenic organisms and to toxins protects the neonate effectively before he has formed active antibody. Studies in human infants and in animals suggest that this early immune response is mainly elicited by antigens derived from gut bacteria and from food $(1,7,21,26)$. For example, human neonates are able to form IgM and IgG antibody to BSA when born after 36 wk of gestation $(19,20)$. Similarly, formation of antibodies to gut bacteria, e.g., to Salmonella $\mathrm{O}$ and $\mathrm{H}$ antigens and to the capsular antigens of $E$. coli has been demonstrated $(22,23)$. Natural antibodies against intestinal bacteria are thought to provide protection against disease because they crossreact with a number of important pathogens $(1-3,16$, 22, 23).

The conditions which govern the immune response to enteric antigens are incompletely understood. Similar to the response of human neonates, the feeding of BSA to adult rabbits regularly results in the formation of active anti-BSA, whereas newborn rabbits and adult rats develop immunologic unresponsiveness after oral application of protein antigens $(17,25)$.

One of the factors that may affect neonatal immune responses is the presence of passive antibody. Studies on the effect of such antibody in human infants have shown suppression or enhancement of antibody formation to parenteral application of diphtheria toxoid $(4,13)$, whereas the response to oral polio vaccine was not affected by either circulating or secretory antibody of the mother (10). No effect of passive antibody on the immune response to BSA was seen in adult rabbits (18).

Interactions between passive antibody and antigen may depend on the type of antigen, the amount of passive antibody present, the time and mode of immunization, and the study model. Application of results from animal studies to humans is difficult, among 
other reasons, because most neonatal laboratory animals have a lower degree of immunologic maturity than human neonates. On the other hand, investigation of the mechanisms operative in oral immunization is important not only for an improved understanding of physiologic and pathologic immune responses to enteric antigens, but it is the prerequisite for the development of oral vaccines. It was the purpose of the present study to investigate the effect of maternal passive antibody to BSA, a normal cow's milk protein, on the immune response to BSA in the human neonate.

\section{MATERIALS AND METHODS}

Infants. 437 samples of maternal or cord sera of healthy fullterm infants were screened for the presence of antibody to BSA. AntiBSA activity was detected in 148 sera $(29.5 \%)$. After the nature and purpose of the study was explained to those mothers, who did not want to breastfeed, informed consent was obtained from 12 women (Group I, passive anti-BSA at birth). Similarly, nine mothers agreed to have their babies participate as controls (Group II, no passive anti-BSA at birth).

Quantitation of circulating antibody to BSA. Anti-BSA was determined by the ammonium sulphate technique (15). Results were expressed as an $\mathrm{ABC}-33$. This term represents the amount of BSA-N that would theoretically be bound by $1 \mathrm{ml}$ of undiluted serum when $0.01 \mu \mathrm{g}\left[{ }^{125} \mathrm{I}\right]-\mathrm{BSA}-\mathrm{N}$ per $\mathrm{ml}$ was the concentration of antigen added. Anti-BSA was considered to be present, if $0.2 \mathrm{ml}$ of a 1:5 dilution of serum specifically bound at least $10 \%$ of the labeled antigen. If sera bound more than $33 \%$ of the labeled antigen, serial dilutions were set up, starting with a 1:5 dilution, and an ABC-33 was calculated. All determinations were done in duplicate.

Determination of antigenic BSA-content of formulas. Commercially available formulas were chosen by the mothers. Four different formulas were used. The amount of antigenic BSA present in the formulas was determined by radioimmune inhibition (15, 17). Formulas were prepared according to the manufacturers' directions with distilled water. After two centrifugations in the cold at $12000 \times g$ for $30 \mathrm{~min}$ to remove fat and particles, antigenic BSA was determined in the whey fraction by comparing the specific inhibition of a standard anti-BSA- $\left[{ }^{125} \mathrm{I}\right]-\mathrm{BSA}$ reaction by each formula, with the inhibition caused by known amounts of unlabeled BSA. Antigen content was expressed as mg BSA/dl of prepared formula.

Determination of anti-BSA isotypes. Isotypes of anti-BSA activity were determined using a direct solid phase ELISA (6). Polystyrol tubes were coated with $5 \mu \mathrm{g} \mathrm{BSA} / \mathrm{ml}$ in $\mathrm{Na}_{2} \mathrm{CO}_{3}$ buffer, a concentration which had been shown to result in optimal binding of serum antibody in prior control experiments. After three washes with isotonic saline containing $0.05 \%$ polysorbate 20 serial dilutions of sera were added, starting with a 1:10 dilution, and incubated for $6 \mathrm{~h}$ at room temperature. After repeated washing, alkaline phosphatase conjugated goat anti-human-antibody directed against IgG, IgA, IgM and IgE (Tago, Inc. Immunodiagnostic Reagents, Burlingame, CA, U.S.A.) was added. Tubes were then incubated overnight at room temperature. Antibody preparations were used in dilutions of 1:5000 (IgG, IgM and $\operatorname{IgA})$ and 1:2500 (IgE), which had been shown to result in optimal absorption values in control experiments. After three more washes, $p$ nitrophenylphosphate was added as substrate and tubes were reincubated for $100 \mathrm{~min}$ at $37^{\circ} \mathrm{C}$. The reaction was stopped by adding $1 \mathrm{~N} \mathrm{NaOH}$ and $\mathrm{OD}$ was measured in a spectrophotometer at $\mathbf{4 0 5} \mathrm{nm}$ against blanks, which had been handled in the same way except that phosphate buffered saline had been added instead of serum. All determinations were done in duplicate.

In control experiments with a direct ELISA using tubes coated with $99 \%$ pure IgG (Behring Werke AG, Marburg/Lahn, West Germany), crossreactivity between anti-IgM-, anti-IgA-, and antiIgE-conjugates with anti-IgG-conjugate was less than $1 \%$. Antigen specificity was tested in the following ways: (1) tubes coated with human serum albumin gave OD values in the range of blanks; (2) preincubation of anti-BSA containing serum with increasing amounts of crystalline BSA $(1 \mathrm{ng} / \mathrm{ml}-1 \mathrm{mg} / \mathrm{ml})$ resulted in pro- gressive specific inhibition. Anti-BSA activity was totally inhibited at a BSA concentration of $10 \mu \mathrm{g} / \mathrm{ml}$; and (3) Forty sera, not included in this study, were tested by the ammonium sulfate technique and IgG-ELISA. Linear regression analysis showed a regression coefficient $r$ of +0.977 . Anti-BSA activity as determined by ELISA was expressed as EU, i.e., the dilution of serum that, under the conditions described above, gave an OD of 0.5 . When OD values lower than 0.5 were found, antibody was considered to be present if ODs of the starting dilution of $1: 10$ exceeded the absorption found with 10 anti-BSA negative cord sera plus three standard deviations of the mean. These 10 sera were considered anti-BSA negative after they had been shown to have $0 \%$ precipitation by the ammonium sulfate technique.

Determination of immunoglobulins. IgG was determined by single radial immunodiffusion in maternal and cord sera and in the infants' sera at 4, 8, and 26 wk of age (Partigen plates, Behring Werke AG, Marburg/Lahn, West Germany).

Statistical calculations. Two-tailed Mann-Whitney U-Test was used for comparison of both groups throughout the paper.

\section{RESULTS}

Development and clinical status of infants. According to the presence of detectable anti-BSA at birth, infants were divided into Group I (anti-BSA present, six males and six females) and Group II (no passive anti-BSA, two males and seven females). There were no differences between the two groups with respect to clinical criteria. All infants were born at term and left the nursery about the fifth day of life. Mean weight \pm 1 S.D. at birth was $3274 \pm$ $400 \mathrm{~g}$ in Group I, and $3374 \pm 509 \mathrm{~g}$ in Group II, respectively (P $>0.05$ ). At 26 wk of life, mean weight \pm 1 S.D. was $8332 \pm 911$ $\mathrm{g}$ for Group I, and $7966 \pm 595 \mathrm{~g}$ for Group II. No infant showed any undue susceptibility to infection or any abnormality related to the immune system with the exception of A.M., who suffered three episodes of otitis media between 4-10 wk of age and had transient hypogammaglobulinemia (IgG at 6 months $1.8 \mathrm{mg} / \mathrm{ml}$, at 2 years $6.5 \mathrm{mg} / \mathrm{ml}$ ). His response to diphtheria immunization was normal and he had no further infections.

Development of total circulating anti-BSA in the infants' sera. Individual responses of both groups to BSA in the milk are shown on Table 1 . At 4 wk, 10 of 12 infants of Group I had detectable anti-BSA in their sera. The concentrations of specific antibody in five of these infants were equal to or higher than at birth, indicating the presence of actively formed antibody. All infants of Group II had detectable circulating anti-BSA by 4 wk of age, although the amounts of antibody in two infants of this Group remained too low for calculation of an ABC-33 throughout the study period.

Mean responses to BSA and mean concentrations of serum IgG in the two study Groups are compared on Figure 1. Although circulating anti-BSA activity in Group II was higher from 4 wk of age throughout the rest of the study period, no significant differences could be demonstrated between the two groups. There was no difference in the development of serum IgG concentrations.

Development of anti-BSA isotypes. Isotypes associated with antiBSA were determined at 4, 8, and 26 wk of age, for IgE-anti-BSA only at 26 wk of age. Results are shown on Table 2 . There were no differences between infants of Group I and Group II. As had been found in previous studies the main isotype associated with anti-BSA was IgG. In fact, development of IgG-anti-BSA concentrations in both groups increased almost in parallel to total antiBSA concentrations as determined by the ammonium sulfate technique. Measurable amounts of IgM-anti-BSA were only found in one infant at $4 \mathrm{wk}$, traces were detected in four of the 11 infants of Group I and in none of three infants of Group II whose sera could be tested. With one exception, no IgM-anti-BSA was found at $8 \mathrm{wk}$. At 26 wk traces of IgM-anti-BSA were again seen in 18 of 19 infants tested. Traces of IgA-anti-BSA were found in most infants tested at 4 and 8 wk. At 26 wk of age, measurable concentrations of IgA antibody were present in 10 of 12 infants of Group I and in six of eight children of Group II. Traces of IgEanti-BSA were seen in eight of nine children of Group $I$ and in five of eight children of Group II. 
Table 1. Development of circulating anti-bovine serum albumin (BSA) in infants with and without passive anti-BSA at birth

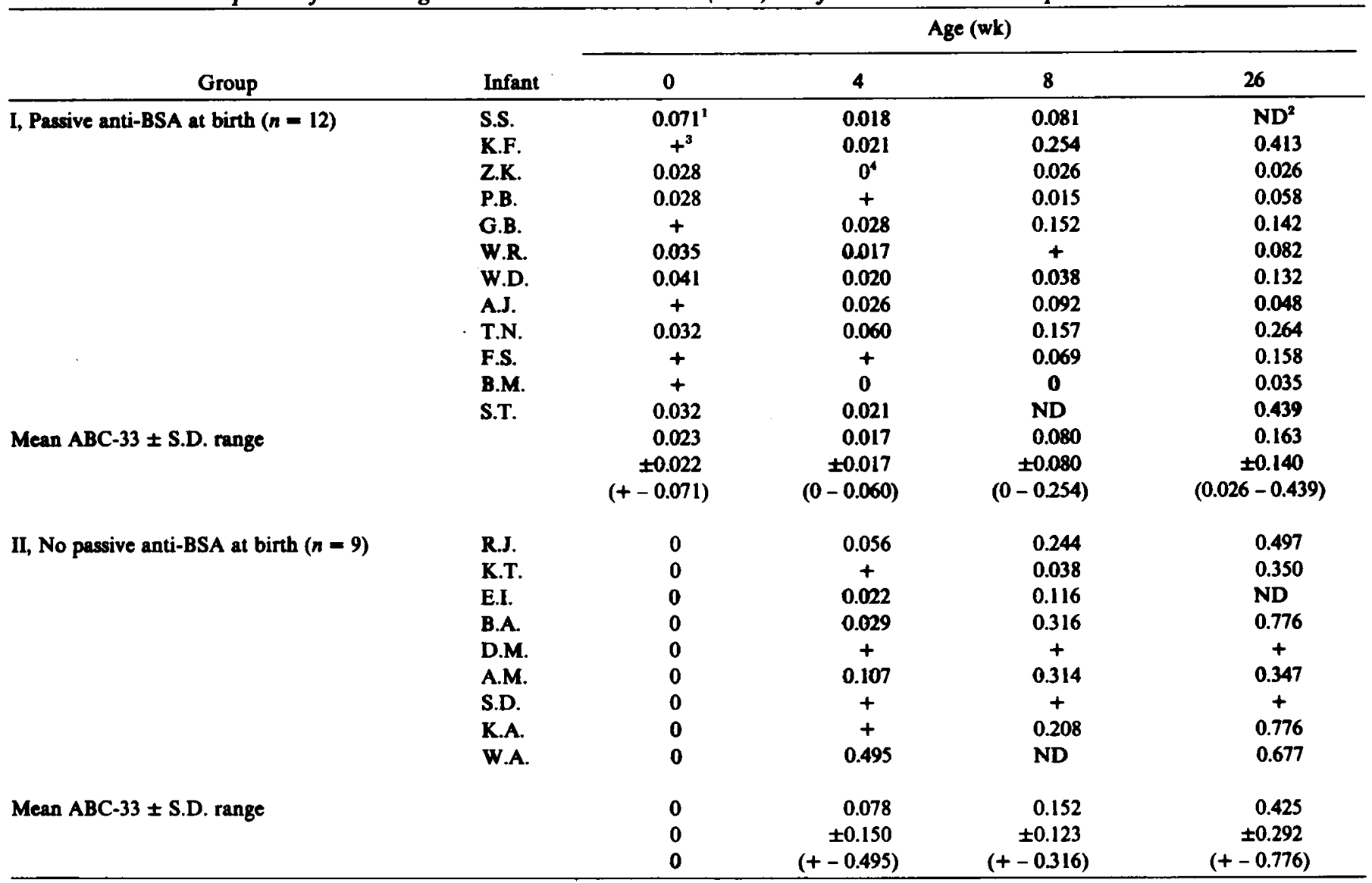

${ }^{1}$ Antigen binding capacity-33 (ABC-33) in $\mu g$ bovine serum albumin-nitrogen/ml of undiluted serum, when $0.01 \mu \mathrm{g}$ l $\left.^{125} \mathrm{I}\right] \mathrm{bovine}$ serum albuminnitrogen $/ \mathrm{ml}$ was the amount of antigen added.

${ }^{2}$ Not done.

${ }^{3}$ Antibody present in insufficient amounts to calculate an ABC-33.

${ }^{4}$ No antibody present.

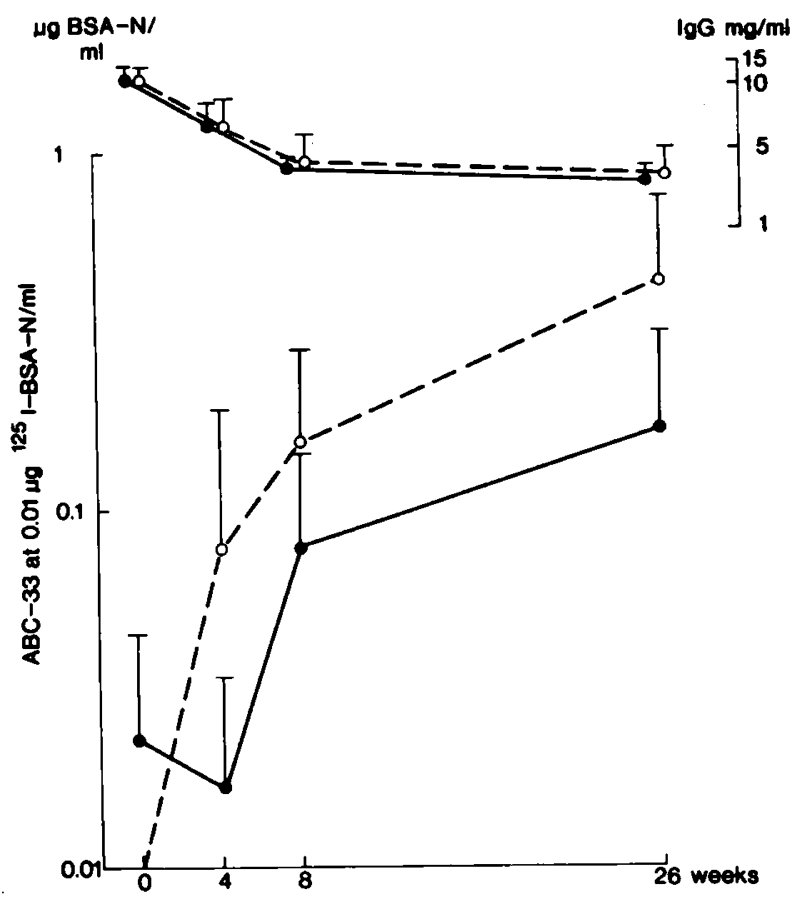

Fig. 1. Development of circulating anti-BSA and IgG in infants with (Group $I, O)$ and without (Group $I I, O$ ) passive anti-BSA at birth.
Antigen content of formula. Four different formulas were used during the study period. The concentrations of antigenic BSA in these formulas were found to be $0.4,0.6,2$, and $4 \mathrm{mg} / \mathrm{dl}$ of formula. Daily intake of BSA therefore ranged from $3.6-30 \mathrm{mg}$ BSA per day. Because four infants in Group I ingested the formula with a BSA content of $0.4 \mathrm{mg} / \mathrm{dl}$ and the other eight infants ingested the formula with a BSA content of $4 \mathrm{mg} / \mathrm{dl}$ at 4 and $8 \mathrm{wk}$ of age, it was possible to compare the antibody response of these two subgroups (Table 3). There was no significant difference among circulating anti-BSA concentrations at birth, 4 , and 8 wk.

Beyond the age of 8 wk the addition of milk cereals and other milk products no longer allowed a fair estimation of BSA intake.

\section{DISCUSSION}

It is generally accepted that GALT within the immune apparatus represents a separate compartment that is closely linked to other compartments of the secretory immune system (24). The recognition and processing of antigens in GALT depend on factors such as digestion, pinocytosis, the function of secretory antibody, and absorption into the portal system or into the chylus. On the other hand, mechanisms that are known to affect the response to parenteral antigens may be of minor importance in the regulation of mucosal immunity. One such factor known to modulate the response to parenteral antigens is passive antibody $(4,12-14)$. For example, the suppressed responses to diphtheria toxoid, when given between $6 \mathrm{wk}$ and 3 months of age, or to measles immunization are attributed to the action of passive maternal antibody 
Table 2. Development of isotypes of anti-bovine serum albumin (BSA) activity in infants at 4, 8, and 26 wk of age with and without passive anti-BSA at birth

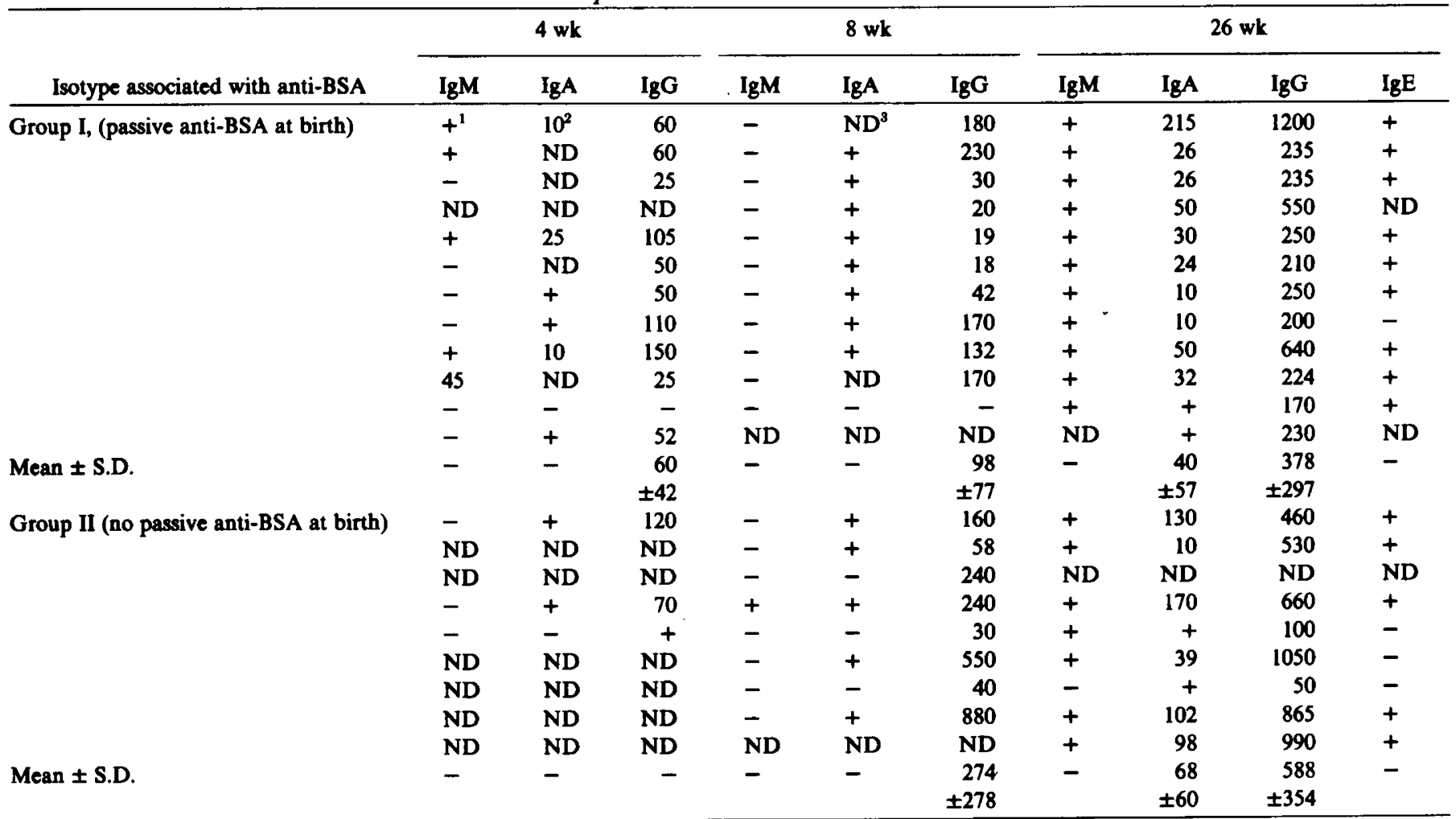

${ }^{1}$ Anti-BSA present in insufficient amount to calculate ELISA units (EU).

2 ELISA-units (EU).

${ }^{3}$ Not done because of insufficient amounts of serum.

Table 3. Comparison of Group I infants ingesting formulas with different concentrations of bovine serum albumin (BSA)

\begin{tabular}{|c|c|c|c|c|}
\hline \multirow[b]{2}{*}{ Infants } & \multirow{2}{*}{$\frac{\text { Average intake/day }}{(\mathrm{mg} \mathrm{BSA})}$} & \multicolumn{3}{|c|}{ Circulating anti-BSA } \\
\hline & & birth & $4 \mathbf{w k}$ & 8 wk \\
\hline $\begin{array}{l}\text { Ingesting formula with high BSA content } \\
(4 \mathrm{mg} / \mathrm{dl}),(n=8)\end{array}$ & $\begin{array}{c}21.9 \pm 5.3^{1} \\
(10-30)^{2}\end{array}$ & $\begin{array}{c}0.018 \pm 0.018 \\
\left(+^{3}-0.041\right)\end{array}$ & $\begin{array}{l}0.017 \pm 0.017 \\
(0-0.060)\end{array}$ & $\begin{array}{c}0.078 \pm 0.083 \\
(0-0.254)\end{array}$ \\
\hline $\begin{array}{l}\text { Ingesting formula with low BSA content } \\
(0.4 \mathrm{mg} / \mathrm{dl}),(n=4)\end{array}$ & $\begin{array}{c}3.6 \pm 0 \\
(3.6)\end{array}$ & $\begin{array}{c}0.024 \pm 0.022 \\
(+-0.071)\end{array}$ & $\begin{array}{c}0.017 \pm 0.01 \\
(+-0.028)\end{array}$ & $\begin{array}{l}0.066 \pm 0.062 \\
(0.038-0.152)\end{array}$ \\
\hline
\end{tabular}

\footnotetext{
${ }^{1}$ Mean \pm S.D.

2 Range.

${ }^{3}$ Antibody present in insufficient amounts to calculate an ABC-33.
}

$(4,12)$. On the other hand, when infants are immunized at 6 months of age, passively transferred maternal antibody in low concentrations may enhance the active antibody response of the infant against diphtheria toxoid (13).

In adult rabbits, passive antibody to BSA was shown to suppress or enhance the response to antigen given parenterally depending on the type and route of immunization and on the amount of passive antibody present. In the same model, passive antibody was found not to interact with either orally applied BSA or to affect the immune response to antigen given by this route (18). In contrast, in mice the induction of tolerance induced by feeding of ovalbumin was reduced by prior injection of passive antibody (9). In the human neonate limited information exists regarding the effect of passive antibody on active immune responses to antigens present at surface membranes of the gut.

Studies on the development of natural antibodies to meningococci in human infants showed a nadir of mean antibody concentrations to the three types of bacteria investigated around 12 months of age; however, there was no period during which no antibodies were found, which suggests that the onset of immunity occurred in the presence of passive antibodies (7). Infants born to mothers with agammaglobulinemia produce circulating immunoglobulins in the low to low normal range suggesting at least that maternal antibody does not exert a suppresssive effect on the infant's active antibody production (11). A steady rise of antibodies to whey proteins during the first 3 months of life was reported in a group of infants fed a commercial formula. Passive antibody to whey proteins had been found in 23 of 25 cord sera in this study (5). Lower IgG antibodies to $\beta$-lactalbumin, $\alpha$-casein and $\beta$-casein were found in the sera of infants after prolonged mixed feeding as compared to infants who had been weaned within less than 1 wk (8). In this study secretory antibodies to the three milk proteins were found in all breast milk samples. These results were interepreted as a suppressive effect of secretory IgA on antibody formation to nutritional protein.

In the present study no significant effect of maternal antibody was seen on the immune response to 10 -fold different concentrations of BSA in the infants formulas. At the age of $4 \mathrm{wk}$, circulating anti-BSA was found in 11 of 12 infants born with passive antibody. In five of these infants the concentrations of specific antibody were equal to or higher than the concentrations measured at birth. This finding and the detection of IgA- or IgM-anti-BSA in eight 
of 10 infants tested suggest that active antibody was formed against food antigens while passive antibody was still circulating.

The height of the immune response in infants with or without passive anti-BSA was comparable to previous studies although no extra BSA was added to the formulas $(19,20)$. This would indicate not only minimal interaction between circulating passive antibody and antigen presented to mucosal surfaces, but also that antibody formation to oral protein antigens occurs over a wide range of antigen concentrations.

No differences between groups were seen regarding the response to the continuing antigen stimulation because both infants with and without passive anti-BSA seemed to continuously increase their antibody concentrations so that by 6 months anti-BSA concentrations were $3-4$-fold higher than at 8 wk of age. The main isotype associated with anti-BSA in both groups was IgG. IgA accounted for approximately $10 \%$ of measurable antibody. Only traces of IgM-anti-BSA were found at $4 \mathrm{wk}$ and at $26 \mathrm{wk}$ of age.

The results of the present study suggest that the initiation of antibody formation to environmental antigens in the gut occurs relatively unaffected by the presence of circulating maternal antibody. Because the importance of passive protection is as vital for the newborn as the development of active immunity, minimal interaction between circulating passive antibody and active antibody formation would seem to be a prerequisite for the immunologic protection of the neonate.

\section{REFERENCES AND NOTES}

1. Argaman, M., Liu, T. Y., and Robbins, J. B.: Polyribitol-Phosphate: an antigen of four gram-positive bacteria cross-reactive with the capsular polysaccharide of Haemophilus influenzae type b. J. Immunol., 112: 648 (1974).

2. Bardana, E. J., McClatchy, J. K., Farr, R. S., and Minden, P.: II. The primary interaction of antibody to components of aspergilli. J. Allergy Clin. Immunol., 50: 222 (1972).

3. Bardana, E. J., McClatchy, J. K., Farr, R. S., and Minden, P.: Universal occurrence of antibodies to Tubercle bacilli in sera from tuberculous and nontuberculous individuals. Clin. Exp. Immunol., 13: 65 (1973).

4. di'Sant-Agnese, P. A.: Combined immunization against diphtheria, tetanus and pertussis in newborn infants. II. Duration of antibody levels; antibody titers after booster dose; effect of passive immunity to diphtheria on active immunization with diphtheria toxoid. Pediatrics, 3: 181 (1949).

5. Eastman, E. J., Lichauco, T., Grady, M. I., and Walker, W. A.: Antigenicity of infant formulas: role of immature intestine on protein permeability. J. Pediatr., 93: 561 (1978).

6. Engvall, E. and Perlmann, P.: Enzyme-linked Immunosorbent Assay (ELISA). Immunochemistry, 8: 871 (1971).

7. Goldschneider, J., Gotschlich, E. C., and Martenstein, M. S.: Human immunity to the Meningococcus. J. Exp. Med., 129: 1327 (1969).

8. Hanson, L. A., Ahlstedt, S., Carlsson, B., and Fallström, S. P.: Secretory IgA antibodies against cows milk proteins in human milk and their possible effect in mixed feeding. Int. Archs. Allergy Appl. Immunol., 54: 457 (1977).

9. Hanson, D. L., Vaz, N. M., Rawlings, L. A., and Lynch, J. M.: Inhibition of specific immune responses by feeding protein antigens. II. Effects of prior passive and active immunization. J. Immunol., 122: 2261 (1979).
10. John, T. J., Devarajan, L. V., Luther, L., and Vijayarathnam, P.: Effect of breastfeeding on seroresponse of infants to oral Poliovirus vaccination. Pediatrics, 57: 47 (1976).

11. Kobayashi, R. H., Hyman, C. J., and Stichm, E. R.: Immunologic maturation in an infant born to a mother with Agammaglobulinemia. Am. J. Dis. Child., 13: 942 (1980).

12. Krugman, S.: Present status of measles and rubella immunization in the United States: a medical progress report. J. Pediatr., 90: 1 (1977).

13. Levi, M. J., Kravtzov, F. E., Levova, T. M., and Formenko, G. A.: The ability of maternal antibody to increase the immune response in infants. Immunology, 16: 146 (1968).

14. McCormick, J. B., Gusmao, H. H., Nahamura, S., Freire, J. B., Veras, J. Gorman, G., Feeley, J. C., and Wingo, P. H.: Antibody response to serogroup $A$ and $C$ Meningococcal polysaccharide vaccines in infants born of mothers vaccinated during pregnancy. J. Clin. Invest., 65: 1141 (1980).

15. Minden, O. and Farr, R. S.: The ammonium sulphate method to measure antigen-binding-capacity. In: Handbook of Experimental Immunology, Ed.: Weir DM, (Blackwell Scientific Publications 1979).

16. Mittal, K. K. Terasaki, P. I., Springer, G. F., Desai, P. R., McIntire, F. C., and Hirata, A. A.: Inhibition of anti-HLA alloantisera by glycoproteins, polysaccharides, and lipopolysaccharides from diverse sources. Transplant. Proc., 5 : 499 (1973).

17. Rieger, C. H. L., Gülden, P., and Byrd, D. J.: Induction of specific tolerance to ingested soluble protein in neonatal rabbits. Immunobiology, 160: 330 (1981).

18. Rieger, C. H. L., Kraft, S. C., and Rothberg, R. M.: Lack of effect of passive immunization on the active immune response to an ingested soluble protein antigen. J. Immunol., 124: 1789 (1980).

19. Rieger, C. H. L. and Rothberg, R. M.: Development of the capacity to produce specific antibody to an ingested food antigen in the premature infant. J. Pediatr., 87: 515 (1975).

20. Rothberg, R. M.: Immunoglobulin and specific antibody synthesis during the first weeks of life of premature infants. J. Pediatr., 75: 391 (1969).

21. Rothberg, R. M. and Farr, R. S.: Antibodies in Rabbits fed milk and their similarities to antibodies in some human sera. J. Allergy, 36: 450 (1965).

22. Schneerson, R. and Robbins, J. B.: Induction of serum Haemophilus influenzae type b capsular antibodies in adult volunteers fed cross-reacting Escherichia coli 075:K 100:45. N. Engl. J. Med., 292: 1093 (1975).

23. Smith, R. T., Eitzmann, D. V., Catlin, M. E., Wirtz, E. O., and Miller, B. E.: Development of immune response: characterisation of response of human infant and adult to immunisation with Salmonella vaccines. Pediatrics, 33: 163 (1964).

24. Svennerholm, A. M., Hanson, L. A., Holmgren, J., Jalil, F., Lindblad, B. S. Khan, S. R., Nilsson, A., and Svennerholm, B.: Antibody responses to live and killed poliovirus vaccines in the milk of Pakistani and Swedish women. J. Infect. Dis., 143: 707 (1981).

25. Thomas, H. C. and Parrott, D. M. V.: The induction of tolerance to a soluble protein antigen by oral administration. Immunology, 27: 631 (1974).

26. Tomasi, T. B. and Grey, H. M.: Structure and function of immunoglobulin. A. Progr. Allergy, 16: 81 (1972).

27. We thank Prof. H. Weitzel for his help in obtaining maternal and cord sera. The excellent technical assistance of Mrs. Eva Goecke and Ms. Gudrun Runge is gratefully acknowledged. We also thank Ms. Ingrid Lasner for secretarial assistance.

28. Requests for reprints should be addressed to: Dr. Wolfgang Müller, Zentrum für Kinderheilkunde und Humangenetik der Medizinischen Hochschule Hannover, Konstanty-Gutschow-Straße 8, D-3000 Hannover 61, Federal Republic of Germany.

29. This research was supported by the Deutsche Forschungsgemeinschaft, DFGGrant, Ri 345/1

30. Received for publication July 15, 1982.

31. Accepted for publication November 29, 1982. 